\title{
AGAMA FORMAL VS KECERDASAN SPRITUAL (ANALISIS KONSELING SPRITUAL TERHADAP FENOMENA KORUPSI)
}

\author{
Devi Adriany \\ Konsentrasi Bimbingan dan Konseling Islam \\ Pascasarjana Universitas Islam Negeri Sunan Kalijaga Yogyakarta \\ (E-mail: deviadriany13@gmail.com)
}

\begin{abstract}
Corruption is a negative action that a person undertakes to gain his own advantage. Not infrequently corruption is done by someone who has a high education and religion. Formal religion is a set of externally charged rules and beliefs. It is top-down, inherited from priests, prophets and scriptures or inculcated through family and tradition. Spiritual intelligence is the intelligence to deal with and solve the problem of meaning and value, the intelligence to gain behavior and live in the context of broader and more rich meaning, the intelligence to judge that one's actions or way of life are more meaningful than others. spiritual intelligence can not be equated with religion. Although some people improve spiritual intelligence through religious approach.But that does not mean people are not religious can not have high spiritual intelligence. Counseling approach to the phenomenon of corruption is spiritual counseling with the method of counselor prayer, then giving information about spiritual concepts, referring to scripture, spiritual disclosure, spiritual confrontation, prayer with counselor and counselee, encouragement, use of community or religious group, counselee prayer and religious bibilioterapi.

Keywords: Corruption, Formal Religion, Spiritual Intelligence, Spiritual Counseling.
\end{abstract}

\begin{abstract}
Abstrak
Korupsi merupakan aksi negatif yang dilakukan seseorang untuk memperoleh keuntungan sendiri. Tak jarang korupsi dilakukan oleh seseorang yang memiliki pendidikan tinnggi dan beragama. Agama formal merupakan seperangkat aturan dan kepercayaan yang dibebankan secara eksternal. Ia bersifat top-down, diwarisi dari pendeta, nabi dan kitab suci atau ditanamkan melalui keluarga dan tradisi. Kecerdasan spritual merupakan kecerdasan untuk menghadapi dan memecahkan persoalan makna dan nilai, yaitu kecerdasan untuk mendapatkan perilaku dan hidup dalam konteks makna yang lebih luas dan kaya, kecerdasan untuk menilai bahwa tindakan atau jalan hidup seseorang lebih bermakna dibandingkan dengan yang lain. kecerdasan spiritual tidak bisa disamakan begitu saja dengan beragama. Walaupun sebagian orang meningkatkan kecerdasan spiritual melalui pendekatan agama tetapi bukan berarti orang tidak beragama tidak mampu memiliki kecerdasan spiritual yang tinggi. Pendekatan konseling terhadap penomena korupsi yaitu konseling spritual dengan metode doa konselor, kemudian pemberian informasi tentang konsep-konsep tentang spritual,
\end{abstract}


merujuk kepada kitab suci, pengungkapan diri spritual, konfrontasi spritual, doa bersama konselor dan konseli, dorongan untuk memaafkan, penggunaan komunitas atau kelompok beragama, doa konseli dan biblio terapi keagamaan. Kata kunci: Korupsi, Agama Formal, Kecerdasan Spritual, Konseling Spritual.

\section{A. Pendahuluan}

Istilah korupsi sudah tidak asing lagi dalam benak kita. Indonesia setelah runtuhnya orde baru harapan segenap lapisan masyarakat antara lain adalah terciptanya pemerintahan yang demokratis, bersih, adil dan bebas dari korupsi. Korupsi yaitu menyalahgunakan, menyimpang, menghancurkan dan mematahkan. Korupsi dalam artian menyalahgunakan yaitu menyalahgunakan wewenang atau kekuasaan, sedangkan menyimpang yaitu menyimpang dari hukum, norma serta moral, dan menghancurkan atau mematahkan yaitu menghancurkan kepercayaan. Korupsi mengandung makna yang sangat negatif karena mengacu pada suatu perilaku yang destruktif dan sangat merugikan. Munculnya korupsi menurut Klgaard karena adanya monopoli kewenangan atau kekuasaan dan minimnya akuntabilitas. Klgaard mendefinisikan korupsi dalam bentuk rumus yaitu $\mathrm{C}=$ $\mathrm{M}+\mathrm{D}-\mathrm{A}$ yaitu $\mathrm{C}=($ Corruption $) \mathrm{M}=($ Monopoly $) \mathrm{D}=($ Discretionary Power $)$ dan $\mathrm{A}=$ (Accountability). Jadi korupsi terjadi karena adanya monopoli kewenangan dan kurangnya atau minimnya akuntabilitas. ${ }^{1}$

Berangkat dari apa yang menyebabkan orang-orang penting yang menurut hemat penulis disini, atau orang-orang intelektual masih saja melakukan penyelewengan atau penyalahgunaan wewenang dalam hal ini korupsi. Disini penulis merasa ingin lebih lanjut meneliti dan melihat faktor-faktor yang menyebabkan seseorang melakukan tindakan korupsi. Apakah karena faktor agama masih kurang kuat dalam membendung seseorang dalam bertindak kejahatan, ataukah karena faktor politik dan sosial, seperti adanya monopoli kewenangan dan minimnya akuntabilitas seperti yang diungkapkan oleh Klgaard diatas, ataukah ada faktor lain seperti kemampuan-kemampuan yang tidak dimiliki seseorang sehingga masih saja melakukan hal-hal yang bersifat negatif ini. Seperti yang dijelaskan oleh Danah Zohar dan Ian Marshall bahwa ketika

${ }^{1}$ Zainal Abidin, A Gimmy Prathama Siswadi, Psikologi Korupsi (Bandung: PT Remaja Rosdakarya, 2015), h. 11 
seseorang memiliki Kecerdasan Spritual (SQ) yang tinggi akan cenderung menjadi seorang pemimpin yang penuh pengabdian yaitu yang bertanggung jawab untuk membawakan visi dan nilai yang lebih tinggi kepada orang lain dan memberikan petunjuk penggunaannya.

Mungkin akan lebih jelas jika dipahami dan dikaji apa sebenarnya maksud dari kecerdasan spiritual yang dimaksudkan oleh Zohar dan Marshall tersebut. Jika dilihat dari Survei CSIS jelang dua tahun kepemimpinan Presiden Joko Widodo, persepsi masyarakat terhadap fenomena korupsi justru meningkat. Dalam hasil survei yang dilakukan Centre for Strategic dan International Studies (CSIS) Indonesia, sebanyak 66,4\% masyarakat menganggap tingkat korupsi di Indonesia justru meningkat jika dibandingkan dengan dua tahun sebelumnya. Hanya sebesar 10,8\% yang menilai tingkat korupsi menurun, dan sebesar 21,3\% menganggap tidak ada perubahan. ${ }^{2}$

Berdasarkan hal tersebut dapat dikatan bahwa fenomena korupsi meningkat dibandingkan dengan tahun sebelumnya. Kondisi tersebut seharusnya tidak menjadikan grafik korupsi semakin meningkat dan seharusnya individu yang memiliki wewenang tidak menyalahgunakan untuk kepentingan pribadi. Untuk mewujudkan kondisi tersebut perlu ada upaya yang dilakukan yaitu dengan menggunakan layanan konseling spritual. Layanan konseling tersebut dipandang efektif untuk meningkatkan kesadaran dan kebermaknaan hidup. Berdasarkan latar belakang permasalahan tersebut disini penulis ingin mengkaji agama formal vs kecerdasan spritual analisis konseling spritual terhadap fenomena korupsi.

\section{B. Landasan Teori}

\section{Agama Formal dan Kecerdasan Spiritual}

Di Indonesia, istilah agama digunakan untuk menyebut enam agama yang diakui resmi oleh negara, seperti Islam, Katolik, Protestan, Hindu, Budha, dan Khonghucu. Agama adalah sebuah koleksi terorganisir dari kepercayaan, sistem budaya dan pandangan dunia yang menghubungkan manusia dengan tatanan/perintah dari kehidupan. Agama formal adalah seperangkat aturan dan

${ }^{2}$ Erandhi Hutomo Saputra, Survei CSIS: Tingkat Korupsi di Indonesia Meningkat, Alamat Web,http://mediaindonesia.com/news/read/58308/survei-csis-tingkat-korupsi-diindonesia-meningkat/2016-07-26, di akses pada hari Senin 24 April 2017, jam 14. 00 Wib 
kepercayaan yang dibebankan secara eksternal. Ia bersifat top-down, diwarisi dari Pendeta, Nabi dan kitab suci atau ditanamkan melalui keluarga dan tradisi. ${ }^{3}$

Sedangkan kecerdasan spritual secara konseptual terdiri atas gabungan kata kecerdasan dan spritual. ${ }^{4}$ Kata spirit berkaitan dengan moral, semangat, dan sukma. Kata spritual sendiri dapat dimaknai sebagai hal-hal yang bersifat spirit atau berkenaan dengan spirit. Sehingga dapat diartikan spritual sebagai suatu hal yang berkaitan dengan kemampuan dalam membangkitkan semangat. Spritual adalah suatu dimensi yang terkesan mahaluas, tak tersentuh, jauh diluar karena Tuhan dalam pengertian Yang Mahakuasa, benda alam semesta yang metafisis dan transenden sehingga sekaligus meniscayakan nuansa mistis dan suprarasional. $^{5}$

Spritual Quetiant atau yang disebut kecerdasan Spiritual adalah kecerdasan untuk menghadapi dan memecahkan persoalan makna dan nilai, yaitu kecerdasan untuk mendapatkan perilaku dan hidup dalam konteks makna yang lebih luas dan kaya, kecerdasan untuk menilai bahwa tindakan atau jalan hidup seseorang lebih bermakna dibandingkan dengan yang lain. ${ }^{6}$ SQ adalah landasan yang difungsikan kecerdasan intelektual (IQ) dan kecerdasan emosional (EQ) secara efektif. Tetapi idealnya ketiga kecerdasan itu bekerja sama dan saling mendukung.

Menurut Ari Ginanjar Agustian dalam buku ESQ, menyebutkan bahwa SQ adalah kemampuan untuk memberi makna ibadah terhadap setiap perilaku dan kegiatan, melalui langkah-langkah dan pemikiran yang bersifat fitrah, menuju manusia yang seutuhnya (hanif), dan memiliki pola pemikiran tauhidi (integralistik), serta berprinsip hanya karena Allah. ${ }^{7}$ Pada dasarnya manusia adalah makhluk spritual karena selalu terdorong oleh kebutuhan untuk mengajukan pertanyaan "mendasar" atau "pokok". Mengapa saya dilahirkan? apakah makna hidup? buat apa hidup dilanjutkan? SQ memungkinkan manusia

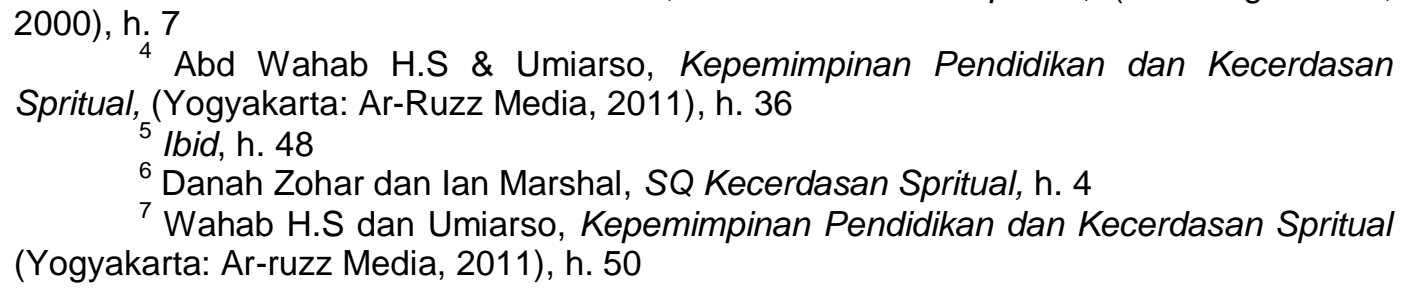

4 Abd Wahab H.S \& Umiarso, Kepemimpinan Pendidikan dan Kecerdasan Spritual, (Yogyakarta: Ar-Ruzz Media, 2011), h. 36

${ }_{5}^{5} \mathrm{Ibid}$, h. 48

${ }^{6}$ Danah Zohar dan Ian Marshal, SQ Kecerdasan Spritual, h. 4

${ }^{7}$ Wahab H.S dan Umiarso, Kepemimpinan Pendidikan dan Kecerdasan Spritual (Yogyakarta: Ar-ruzz Media, 2011), h. 50

${ }^{3}$ Danah Zohar dan Ian Marshal, SQ Kecerdasan Spritual, (Bandung: Mizan, 
menjadi kreatif, mengubah aturan atau situasi. SQ memungkinkan untuk bermain dengan batasan, memainkan permainan tak terbatas dan SQ memberikan kemampuan membedakan. SQ memberi kita rasa moral, kemampuan menyesuaikan aturan yang kaku dibarengi dengan pemahaman dan cinta serta kemampuan setara untuk melihat kapan cinta dan pemahaman sampai pada batasannya. Dengan demikian Kecerdasan spiritual adalah kecerdasan jiwa. ${ }^{8}$

SQ beroperasi dari pusat otak, yaitu fungsi-fungsi penyatu otak. SQ mengintegrasikan semua kecerdasan. SQ menjadikan kita sebagai makhluk yang benar-benar utuh secara intelektual, emosional dan spiritual. Inti dari pengertian tentang SQ tersebut adalah ada dua hal, yaitu ibadah dan hidup yang bermakna. ${ }^{9}$ Dari berbagai pengertian di atas dapat di pahami bahwa Spritual Quotiont atau yang disebut dengan kecerdasan spritual adalah kecerdasan jiwa yang dimiliki oleh individu yang menjadikan dirinya benar-benar utuh secara intelektual, emosional dan spritual dalam memahami makna dan nilai-nilai hidup yang menjadikan jalannya akan lebih bernilai dan bermakna.

Zohar dan Marshall mengungkapkan bahwa kecerdasan spiritual terdiri dari dimensi-dimensi sebagai berikut:

a. Kemampuan bersikap fleksibel yaitu dapat menempatkan diri dan menerima pendapat orang lain secara terbuka.

b. Tingkat kesadaran diri yang tinggi seperti kemampuan memahami dan mengerti tujuan serta visi hidupnya.

c. Kemampuan untuk menghadapi dan memanfaatkan hal-hal yang menyulitkan yang ditandai dengan tidak adanya penyesalan, tetap tersenyum, dan bersikap tenang.

d. Kemampuan menghadapi dan menyembuhkan rasa sakit yang ditandai dengan munculnya sikap ikhlas dan pemaaf.

e. Kualitas hidup yang diilhami oleh visi dan nilai-nilai seperti prinsip dan pegangan hidup dan berpijak pada kebenaran.

\footnotetext{
${ }^{8}$ Danar Zohar dan IAN Marshall, SQ Kecerdasan Spritual, (Bandung: Mizan, 2000), h. 4

Ani Agustiyani Maslahah, Pentingnya Kecerdasan Spritual Dalam Menangapi Perilaku Menyimpang, Jurnal Vol 4 No 1 Tahun Juni 2013, h. 3
} 
f. Keengganan untuk menyebabkan kerugian yang tidak perlu misalnya menunda pekerjaan dan cenderung untuk berpikir sebelum bertindak.

g. Kecenderungan melihat keterkaitan antara berbagai hal atau memiliki pandangan yang holistik yakni mampu untuk berpikir secara logis dan berlaku sesuai dengan norma sosial.

h. Kecenderung menanyakan "mengapa" atau "bagaimana" jika akan mencari jawaban-jawaban yang mendasar dan memiliki kemampuan untuk berimajinasi, serta memiliki rasa ingin tahu yang tinggi.

i. Mudah untuk bekerja melawan konvensi (adat dan kebiasaan sosial), seperti mau memberi dan tidak mau menerima. ${ }^{10}$

Perlu kita pahami bahwa kecerdasan Spritual (SQ) tidak mesti berhubungan dengan agama. Bagi sebagian orang SQ mungkin menemukan cara pengungkapan melalui agama formal, tetapi beragama tidak menjamin SQ tinggi. Banyak orang humanis dan ateis memiliki SQ sangat tinggi, sebaliknya, banyak orang yang aktif beragama memiliki SQ sangat rendah. Beberapa penelitian oleh psikolog Gordon Allport, lima puluh tahun silam, menunjukkan bahwa orang memiliki pengalaman keagamaan lebih banyak di luar batas-batas arus utama lembaga keagamaan daripada di dalamnya. ${ }^{11}$

Dengan demikian kecerdasan spiritual tidak bisa disamakan begitu saja dengan beragama. Walaupun sebagian orang meningkatkan kecerdasan spiritual melalui pendekatan agama. Tetapi bukan berarti orang tidak beragama tidak mampu memiliki kecerdasan spiritual yang tinggi.

\section{Korupsi}

Istilah korupsi berasal dari bahasa latin, yakni corruption atau corruptus yang disalin dalam bahasa Inggris menjadi corruption atau corrupt, dalam bahasa Perancis menjadi corruption dan dalam bahasa Belanda disalin menjadi corruptie (korruptie). Asumsi kuat menyatakan bahwa dari bahasa Belanda inilah kata itu turun ke bahasa Indonesia, yaitu Korupsi. Arti harfiah dari kata korupsi ialah kebusukan, keburukan, kebejatan, ketidakjujuran, dapat disuap, tidak bermoral,

${ }^{10}$ Ekawaty Rante Liling, Firmanto Adi Nurcahyo, Karin Lucia Tanojo, Hubungan Antara Kecerdasan Spritual dengan Prokrastinasi Pada Mahasiswa Tingkat Akhir, Jurnal Humanitas Vol, X No. 2 Tahun 2013, h. 62

${ }^{11}$ Danah Zohar dan Ian Marshal, SQ Kecerdasan Spritual, h. 8 
penyimpangan dari kesucian, kata-kata atau ucapan yang menghina atau memfitnah. $^{12}$

Kamus Besar Bahasa Indonesia memuat pengertian korupsi sebagai “penyelewengan atau penggelapan (uang negara atau perusahaaan, dan sebagainya untuk keuntungan pribadi atau orang lain). ${ }^{13}$

Dari uraian pengertian sederhana diatas, dapat dipahami bahwa arti dan kandungan makna korupsi sangat luas, tergantung dari bidang dan perspektif pendekatan yang dilakukan. Dari semua arti secara etimologis maupun terminologis, korupsi mempunyai arti yang semuanya mengarah kepada keburukan, ketidakbaikan, kecurangan bahkan kezaliman, yang akibatnya akan merusak dan menghancurkan tata kehidupan keluarga, masyarakat, bangsa, dan negara.

Dalam peraturan bernegara khususnya di Indonesia sudah memberikan sanksi terhadap tindak pidana korupsi. Kasus korupsi akan diselesaikan pihakpihak berwajib dari pemerintah. Seperti undang-undang yang mengatur dalam kasus ini sudah banyak pasal-pasal yang menetapkan sanksi-sanksi terkait masalah tindak pidana korupsi seperti salah satu pasal dibawah ini menyatakan.

Undang-Undang Republik Indonesia Nomor 20 tahun 2001 tentang Pemberantasan Tindak Pidana Korupsi Pasal 2 ayat (1) menjelaskan bahwa setiap orang yang secara melawan hukum melakukan perbuatan memperkaya diri sendiri atau orang lain suatu korporasi yang dapat merugikan keuangan negara atau perekonomian negara, dipidana dengan pidana penjara seumur hidup atau pidana penjara paling singkat 4 tahun dan paling lama 20 tahun dan denda paling sedikit Rp.200.000.000 (dua ratus juta rupiah) dan paling banyak Rp.1.000.000.000 (satu miliar rupiah).

Dengan demikian sebenarnya tindakan pemerintah yang membuat sanksisanksi ini bagi pelaku korupsi akan meminimalkan bahkan mendorong para pejabat negara untuk tidak menyalahgunakan keuangan negara. Tetapi, walaupun hal ini sudah dilaksanakan oleh pemerintah masih ada saja penyalah gunaan

\footnotetext{
33.

${ }^{13}$ Departemen Pendidikan dan Kebudayaan, Kamus Besar Bahasa Indonesia, (Jakarta: Balai Pustaka), h. 527
}

${ }^{12}$ M. Nurul Irfan, Korupsi Dalam Hukum Pidana Islam, (Jakarta: Amzah, 2014), h. 
keuangan negara. Padahal sudah jelas bahwa akan dijerat hukum baik denda maupun penjara bagi pelaku korupsi. Ini suatu fenomena yang begitu ekstrem menurut hemat penulis. Sehingga berbagai sudut pandang memberikan komemtar terhadap identifikasi penyebab kasus ini, seperti pengamat politik, pengamat sosial, dan tidak terlepas dari ahli-ahli psikologi.

Berbagai perspektif dari para ahli dalam menentukan faktor penyebab kasus ini, seperti yang dijelaskan oleh Baharuddin Lopa dalam bukunya M. Nurul Irfan bahwa penyebab terjadinya korupsi di Indonesia awalnya disebabkan karena kondisi sosial ekonomi yang rawan sehingga orang melakukan korupsi dengan motif mempertahankan hidupnya. Akan tetapi, kian lama motif ini bergeser menjadi motif ingin memperoleh kemewahan hidup. Penyebab lainnya adalah berupa kelemahan mekanisme organisasi dan tidak dilaksanakannya fungsi pengawasan secara wajar. Hal ini akan mendorong seseorang yang tidak kuat imannya melakukan korupsi. ${ }^{14}$

Beberapa faktor lainnya adalah berupa penegakan hukum yang tidak konsisten, penyalahgunaan kekuasaan atau wewenang, langkanya lingkungan yang antikorup rendahnya pendapatan penyelenggara negara, kemiskinan dan keserakahan, budaya memberi upeti, imbalan dan hadiah, konsekuensi bila ditangkap lebih rendah daripada keuntungan korupsi, budaya permisif/serba membolehkan, tidak mau tahu, serta gagalnya pendidikan agama dan etika. ${ }^{15}$ Disini Baharuddin Lopa melihat adanya keterkaitan antara pendidikan agama dan etika terhadap tindakan-tindakan yang menyalahgunakan keuangan negara. Implikasi pendidikan agama sangat signifikan dalam mendorong seseorang mencegah dirinya dan orang lain dari tindakan kejahatan.

Tetapi Zohar dan Marshaall menjelaskan adanya keterkaitan pemahaman spiritual terhadap kebahagiaan dan kebermaknaan hidup. Ketika seseorang menyadari arti dan makna seorang pemimpin untuk apa ia dipercayai oleh rakyat, ia akan jauh dari sikap-sikap dan tindakan yang buruk. Kecerdasan spiritual akan membantu seseorang dalam menyembuhkan dan membangun diri secara utuh.

\footnotetext{
${ }^{14}$ M. Nurul Irfan, Korupsi Dalam Hukum Pidana Islam, h. 36

${ }^{15}$ Ibid, h.37
} 
Walaupun itu tidak harus diperoleh dari agama, dengan kata lain sekalipun ia seorang ateis.

Terhadap faktor penyebab korupsi yang disebutkan Baharuddin Lopa, gagalnya pendidikan agama dan etika, sebenarnyaberasal dari pemikiran Franz Magnis Suseno, yang mengatakan bahwa agama telah gagal menjadi pembendung moral bangsa dalam mencegah korupsi karena perilaku masyarakat yang memeluk agama itu sendiri. Pemeluk agama menganggap bahwa agama hanya berkutat pada masalah bagaimana cara beribadah saja sehingga agama nyaris tidak berfungsi dalam memainkan peran sosial.

Akan tetapi disini penulis lebih cenderung kepada pendapat Zohar dan Marshall tentang signifikansi kecerdasan spiritual (SQ) terhadap kebermaknaan hidup, yang menurut hemat penulis masih banyak para pejabat pemerintahan krisis nilai dan makna sehingga masih mementingkan dirinya daripada warga negaranya. Tetapi penulis tidak menafikan faktor-faktor lain seperti yang sudah dijelaskan sebagian ahli di atas. Dengan demikian, penulis mengambil kesimpulan bahwa faktor penyebab korupsi secara umum dapat diklasifikasikan menjadi dua macam, yaitu faktor internal dan faktor eksternal. Faktor internal berkaitan dengan pelaku korupsi itu sendiri sebagai pemegang amanat berupa jabatan dan wewenang yang diembannya. Sedangkan faktor eksternal berupa sistem pemerintahan dan kepemimpinan serta pengawasan yang tidak seimbang sehingga bisa membuka peluang terjadinya korupsi.

Untuk megetahui psikologis pelaku korupsidi indonesia dengan meminta kesediaan partisipan dlaam menjawab angket. Penelitian telah dilakukan dengan meminta kesediaan seratus partisipan dalam mengisi angket dan melakukan focus group discussion. Partisapan tersebut yaitu para terpidana yang sudah dinyatakan bersalah oleh pengadilan. Hasil dari angket tersebut menyakatan bahwa pada umumnya mereka tidak tahu pasal-pasal apa yang menjerat mereka sehingga mereka divonis bersalah dan harus masuk penajara. ${ }^{16}$

Psikologis perilaku korupsi di lihat dari tiga bagian yaitu pertama dilihat dari segi ke pribadian pelaku korupsi tersebut. Bahwa pada umumnya memiliki

${ }^{16}$ Zainal Abidin, A Gimmy Prathama Siswadi, Psikologi Korupsi, (Bandung : PT Remaja Rosdakarya, 2015), h. 122. 
tipe ke pribadian dengan traits agreeableness dan conscientiousness tinggi tetapi oppenes relatif rendah. Pada dasarnya Opennes mengindikasikan bahwa seseorang itu memiliki potensi untuk maju dan berprestasi dengan membuka diri pada pengetahuan-pengetahuan baru. Akan tetapi tidak dijadikan sebagai prioritas dalam hidup atau karir nya. Secara umum nampaknya hanya lebih mengutamakan keharmonisan dengan orang lain dan bukannya memberi prioritas pada prestasi dan keterbukaan pada masa depan. Selain itu pelaku menunjukkan kepatuhan terhadap otoritas dan daya kerja sebagai seorang pelaksana bukan sebagai seorang high achiever.

Kemudian psikologis pelaku korupsi dilihat dari motifnya. Motivasi paling tinggi dari pelaku korupsi yaitu power motive, lalu affiliation motive, dan terendah adalah achievement motive. Dikarenakan power motive pelaku korupsi paing tinggi dibandingkan dengan motif-motif lainnya, dapat dipahami bahwa pada umumnya orang yang melaukan korupsi yaitu orang yang memiliki jabatan paling tinggi di pemerintahan maupun di dunia bisnis. Artinya jika di jelaskan dengan teori Maslow bahwa kebutuhan mereka sudah bukan lagi pada taraf fisiologis, rasa aman, dan menjalin relasi dengan orang lain melainkan pada taraf kebutuhan untuk dihargai. Dengan demikian dapat disimpulkan dilihat dari psikologis pelaku korupsi, mereka melakukan korupsi karena power motive mereka sangat tinggi sehingga mereka hanya membutuhkan rasa untuk di hargai dan direalisasikan melalui upaya mengejar kekuasan terutama kekuasaan yang bersifat personal.

Psikologi pelaku dilihat dari locus of control, seorang individu yang locus of controlnya masuk dalam kategori chance, cenderung berperilaku berdasarkan pada persepsinya tentang ada tidaknya peluang atau kesempatan yang bersifat eksternal. Jika kesempatan atau peluang untuk melakukan korupsi ditempat kerja terbuka lebar, maka besar kemungkinan akan melakukan korupsi. ${ }^{17}$

\section{Pendekatan Konseling Terhadap Kasus Korupsi}

Pendekatan konseling terhadap Kasus korupsi yaitu dengan konseling spritual. Konseling spritual merupakan gabungan dari konseling dan spritual. Konseling yaitu salah satu bentuk pelayanan yang mengacu pada keempat dimensi

${ }^{17}$ Zainal Abidin, A Gimmy Prathama Siswadi, Psikologi Korupsi (Bandung : PT Remaja Rosdakarya, 2015). 
kemanusiaan dalam rangka mewujudkan manusia seutuhnya. Dalam proses konseling seorang konselor hendaknya melaksanakan perannya secara optimal melalui berbagai jenis layanan yang dapat diberikan. Konseling bertujuan secara langsung pada tegak dan berkembangnya kehidupan unggul yang mensejahterakan dan membahagiakan. Tujuan konseling secara lebis spesifik yaitu tertuju kepada kondisi pribadi konseli yang unggul dan mandiri, dapat mengendalikan diri, lebih sukses, maju dan berkehidupan efektif dalam kesehariannya. $^{18}$

Konseling memegang tugas dan tanggung jawab yang penting untuk mengembangkan lingkungan, membangun interaksi dinamis antara individu dengan lingkungan. Konseling dibutuhkan secara khusus dan lebih terarah untuk memperkuat atau bahkan merehabilitasi kondisi kemandirian, pengendalian diri, kesuksesan, kemajuan dan kehidupan efektif sehari-hari. ${ }^{19}$

Spritualitas yaitu bagian terpenting dari pengalaman manusi yang merupakan dasar untuk memahami bagaimana individu membangun pengetahuan yang bermakna sehingga dapat membantu individu untuk dapat menemukan makna sosial dan pribadi mereka guna memunculkan kesadaran dalam memaknai setiap perubahan atau perkembangan masalah yang muncul dari perubahan tersebut. Setiap individu memiliki kemampuan yang berbeda-beda dalam memaknai secara positif perubahan serta masalah dalam hidupnya. Yang perlu dipahami tentang spritual yaitu bahwa tidak mesti berhubungan dengan agama. Ramdani menyatakan bahwa spritual adalah kecerdasan jiwa yang dapat membntu seseorang membangun dirinya secara utuh. Kaitannya dengan kecerdasan menurut Zohar \& Marshall yaitu kecerdasan spritual adalah kecerdasan untuk menghadapi dan memecahkan persoalan makna dan nilai untuk menempatkan perilaku dan hidup dalam konteks makna yang lebih luas dan kaya serta menilai bahwa tindak atau jalan hidup seseorang lebih bermakna dibandingkan dengan yang lain. ${ }^{20}$

${ }^{18}$ Rahmah, Pendekatan Konseling Spritual Pada Lanjut Usia (LANSIA) Jurnal "Al-Himar Vol. 03, No. 05 Januari-Juni 2015.

19 Ramdani, Pengembangan Konsep Spritual Dalam Pelaksanaan Layanan Konseling, Jurnal KOPASTAVol. 3 No. 2 Tahun 2016 2000).

${ }^{20}$ Danah Zohar dan Ian Marshal, SQ Kecerdasan Spritual, (Bandung: Mizan, 
Konseling spritual yaitu sebuah proses pemberian bantuan kepada konseli agar memiliki kemampuan untuk mengembangkan fitrahnya sebagai makhluk beragama (homo religious), berperilaku sesuai dengan nilai-nilai agama, dan mengatasi masalah-masalah kehidupan melalui pemahaman, keyakinan, dan praktik-praktik ibadah ritual agama yang dianutnya. ${ }^{21}$ Konseling spritual juga mengarahkan konseli kepada tuhan dengan asusmsi dasar bahwa manusia adalah makhluk yang beragama dan ciptaan tuhan. Dengan demikian dapat disimpulkan bahwa konseling spritualitas merupakan sebuah layanan konseling melalui pendekatan spritualitas dalam membantu menyelesaikan masalah konseli agar hidupnya lebih bermakna dan memiliki nilai, hidup dengan kemandirian dan mampu mengetahui fungsi atau perannya sebagai manusia.

Dalam meyelesaikan permasalahan konseli pendekatan konseling spritual yaitu ditentukan oleh proses perilaku individu. Konseling membantu memahami diri konseli dan kondisi lingkungan. Konseling berorientasi pada kerja sama bukan suatu paksaan terhadap individu untuk mengikuti konseling. Dan konseling terjadi karena adanya kebersamaan atau kerelaan diantara konseli tersebut. Dalam proses konseling seorang konselor tidak boleh abai terhadap isu-isu nilai pribadi, spritualitas dan religiusitas konseli. Konseling spritual bukan layanan yang bebas nilai, akan tetapi layanan syarat nilai. Nilai-nilai pribadi konseli harus dikenali oleh konselor dan juga konselor harus menggali agama konselinya.

Pada dasarnya proses konseling spritual merupakan model elaborasi atau kolaborasi dari proses konseling lainnya dengan menyematkan unsur agama di dalamnya. Dalam proses penyelasaian masalah yang khususnya berkaitan dengan masalah korupsi yang notabenya kebanyakan dilakukan oleh orang yang memiliki pengetahuan (IQ) tinggi maka metode yang diberikan konselor dalam proses konseling yaitu :
a. Meningkatkan pemahaman dasar keyakinan
b. Mengembangkan perasaan
c. Memberikan semangat baru dalam kehidupan
d. Membantu untuk melampaui batas transced
e. Memprediksi rancangan tingkah laku diri secara prosedural

${ }^{21}$ Rahmah, Pendekatan Konseling Spritual Pada Lanjut Usia (LANSIA) Jurnal "Al-Himar Vol. 03, No. 05 Januari-Juni 2015 
f. Mampu mempercepat perkembangan diri. ${ }^{22}$

Selain metode yang dipaparkan di atas teknik-teknik konseling spritual dalam terhdap pelaku kasus korupsi dengan menggunakan konseling spritual yaitu menurut Syamsu Yusud ada sepuluh teknik:

1) Doa konselor

2) Pemberian informasi tentang konsep-konseo tentang spritual

3) Merujuk kepada kitab suci

4) Pengungkapan diri spritual

5) Konfrontasi spritual

6) Doa bersama konselor dan konseli

7) Dorongan untuk memaafkan

8) Penggunaan komunitas atau kelompok beragama

9) Doa konseli

10) Bibilioterapi keagamaan ${ }^{23}$

Teknik konseling spritual di atas dapat diaplikasikan ketika memberikan layanan konseling dalam menyelasaikan permasalahan konseli agar konseli dapat kembali menemukan kebermaknaan hidup.

\section{Pembahasan}

Dalam kasus tindak pidana korupsi pendekatan konseling yang dilkukan yaitu konseling spritual. Konseling merupaakan upaya dalam memfasilitasi individu mencapai tingkat perkembangan yang optimal, pengembangan perilaku yang efektif, pengembangan lingkungan dan peningkatan fungsi atau manfaat individu dalam lingkungannya. Konseling merupakan proses pertemuan anatara konselor dengan konseli baik dengan perorangan maupun dengan kolompok untuk menciptakan kemandirian konseli dan bisa berkembang secara optimal berdasarkan norma-norma yang berlaku. ${ }^{24}$ Implementasi dari hal tersebut salah satunya yaitu dengan cara menerapkan model berpikir yang cerdas secara spritual sehingga dapat membantu individu untuk dapat memaknai kehidupan dan menemukan kembali tujuan hidupnya.

${ }^{22}$ Agus Santoso, Psiko Spritual Konseling Ibnu Qayyim, (Surabaya: Dakwah Digital Press, 2010), h 81

23 Darimis, REM-BEKAS (REVOLUSI MENTAL BERBASIS KONSELING SPRITUAL TEISTIK)Upaa Membangun Generasi Berkarakter FAST, Jurnal Ta'dib Vol. 18 No. 1 Juni 2015

24 Ramdani, Pengembangan Konsep Spritual Dalam Pelaksanaan Layanan Konseling, Jurnal Kopasta, Vol 3 No 2 Tahun 2016, h. 115. 
Pengetahuan dasar yang perlu dipahami yaitu bahwa spriual tidak harus berhubungan dengan agama. Spritual merupakan kecerdasan jiwa yang dapat membantu seseorang membangun dirinya secara utuh. Kaitannya dengan kecerdasan menurut Zohar \& Marshall kecerdasan spritual merupakan kecerdasan untuk menghadapi dan memecahkan makna yang lebih luas dan kaya serta menilai bahwa tindakan atau jalan hidup seseorang leih bermakna dibandingkan dengan yang lain. $^{25}$ Berdasarkan pendapat di atas dapat ditarik kesimpulan bahwa spritualitas merupakan bagian yang paling penting dalam kehidupan manusia dan merupakan dasar bagi seseorang untuk memahami dan bagaimana sesorang itu dalam membangun pengetahuan yang bermakna sehingga individu dapat menemukan makna serta tujuan hidupnya.

Konsep konseling spritual terhadap fenomena korupsi dengan menekankan pembentukan pribadi konseli agar mampu memaknai hidup serta pekerjaan secara positif. Tujuan konseling spritual dalam prose pertolangan bagi para koruptor yaitu sebagai upaya membantu membangkitkan kesadaran dan semangat kepercayaan yang telah menyimpang dari nilai-nilai normatif dan ajaran agamanya, dikarenakan adanya kekosongan jiwa. Dengan membantu konseli berkembang sesuai dengan eksistensinya dan fitrahnya dalam mencapai tujuan hidup dan kebermaknaan hidup. Metode konselinga yang ditawarkan di atas konseling bagi konseli atau pelaku korupsi hendaknya ditangani secara holistik dengan menggunakan metode yang terpadu. Konseling yang diberikan bukan hanya sebatas memberikan pertolongan saja akan tetapi konseling yang diberikan diarahkan untuk mengembalikan keimanan dan ketakwaan serta kesadaran spritual, yang akan membawa konseli pada eksistensi dirinya dan dapat menemukan citra dirinya, dapat menemukan makna dan nilai dalam hidup nya sesuai dengan kebenaran yang hakiki. ${ }^{26}$

${ }^{25}$ Danah Zohar dan lan Marshal, SQ Kecerdasan Spritual, (Bandung: Mizan, 2000), h. 80.

${ }_{26}$ Cucu Maesarah, Pendekatan Konseling Spritual Untuk Mengembangkan Hikmah Ibadah Bagi Pemulihan Pecandu Napza (Penelitian Tindakan Kolaboratif dalam Upaya Mengembangkan Hikmah lbadah untuk Mencapai Perkembangan Kemampuan Bio-Psiko-Sosio-Spritual Pecandu NAPZA di balai Pemulihan Sosial Pamardi Putra Lembang Bandung) http://boharudin.blogspot.co.id/2011/05/pendekatan-konselingspiritual-untuk.html diakses pada tgl 11 Juni 2017 Pukul 15:00 WIB 
Dalam konseling spritual konsep yang perlu dikembangan dalam proses konseling bagi konseli yaitu konsep spritual yaitu merupakan pembentukan pribadi konseli yang memiliki pemikiran yang kritis mengenai konsep keberadaan dirinya berkaitan dengan permasalahan yang dihadapinya dengan menggunakan proses perenungan akan berbahgai konsep. Konsep yang selanjutnya yaitu pembentukan pribadi konseli dengan tujuan untuk memaknai hidup dan menguasai tujuan hidup berlandaskan pada fisik dan mental. Penerapan konsep ini dengan pengalaman-pengalaman yang telah dilalui oleh konseli sehingga diperoleh kesadaran tentang kelemahan serta kekurangan diri. Kemudian yang perlu dalam layanan konseling spritual yaitu membentuk individu untuk mengembangkan kesadarn diri dalam berbagai situasi yang terwujud dalam suatu kebijaksanaan. Proses konseling tersebut dapt melatih konseli untuk membangkitkan kesadaran dirinya.

\section{Kesimpulan}

Kecerdasan spiritual adalah kemampuan potensial setiap manusia yang menjadikan ia dapat menyadari dan menentukan makna, nilai, moral, serta cinta terhadap kekuatan yang lebih besar dan sesama makhluk hidup, karena merasa sebagai bagian dari keseluruhan. Sehingga membuat manusia dapat menempatkan diri dan hidup lebih positif, dengan penuh kebijaksanaan, kedamaian, dan kebahagiaan yang hakiki. Kemudian kecerdasan spiritual tidak mesti berhubungan dengan agama. Dengan kata lain seorang ateis pun mampu memiliki kecerdasan spiritual yang tinggi, agama tidak menjamin kecerdasan spiritual akan tinggi. Tetapi juga tidak menafikan bahwa tidak ada pengaruh agama terhadap kecerdasan spiritual. Terhadap faktor penyebab seseorang melakukan tindakan korupsi banyak ahli yang memberi komentar dalam hal ini, tetapi penulis menyimpulkan dan mengklasifikasikan secara umum terdapat dua macam, yaitu faktor internal yaitu berkaitan dengan pelaku korupsi itu sendiri sebagai pemegang amanat berupa jabatan dan wewenang yang diembannya. Dan faktor eksternal berupa sistem pemerintahan dan kepemimpinan serta pengawasan yang tidak seimbang sehingga membuka peluang terjadinya korupsi.

Pendekatan konseling terhadap pelaku korupsi dengan konseling spritual yaitu dengan menekankan pembentukan pribadi konseli agar mampu memaknai 
hidup serta pekerjaan secara positif. Tujuan konseling spritual dalam prose pertolangan bagi para koruptor yaitu sebagai upaya membantu membangkitkan kesadaran dan semangat kepercayaan yang telah menyimpang dari nilai-nilai normatif dan ajaran agamanya, dikarenakan adanya kekosongan jiwa. Dengan membantu konseli berkembang sesuai dengan eksistensinya dan fitrahnya dalam mencapai tujuan hidup dan kebermaknaan hidup. 
Daftar Pustaka

Abd Wahab H.S \& Umiarso, 2011, Kepemimpinan Pendidikan dan Kecerdasan Spritual, Yogyakarta: Ar-Ruzz Media.

Ani Agustiyani Maslahah, Pentingnya Kecerdasan Spritual Dalam Menangapi Perilaku Menyimpang, Jurnal Vol 4 No 1 Tahun Juni 2013.

Agus Santoso, Psiko Spritual Konseling Ibnu Qayyim, Surabaya: Dakwah Digital Press, 2010

Cucu Maesarah, Pendekatan Konseling Spritual Untuk Mengembangkan Hikmah Ibadah Bagi Pemulihan Pecandu Napza (Penelitian Tindakan Kolaboratif dalam Upaya Mengembangkan Hikmah Ibadah untuk Mencapai Perkembangan Kemampuan Bio-Psiko-Sosio-Spritual Pecandu NAPZA di balai Pemulihan Sosial Pamardi Putra Lembang Bandung) http://boharudin.blogspot.co.id/2011/05/pendekatan-konseling-spiritualuntuk.html diakses pada tgl 11 Juni 2017 Pukul 15:00 WIB

Danah Zohar dan Ian Marshall, 2000, SQ Kecerdasan Spritual, Bandung: Mizan.

Darimis, REM-BEKAS (REVOLUSI MENTAL BERBASIS KONSELING SPRITUAL TEISTIK)Upaa Membangun Generasi Berkarakter FAST, Jurnal Ta'dib Vol. 18 No. 1 Juni 2015

Departemen Pendidikan dan Kebudayaan, Kamus Besar Bahasa Indonesia, Jakarta: Balai Pustaka.

Erandhi Hutomo Saputra, Survei CSIS: Tingkat Korupsi di Indonesia Meningkat, Alamat Web http://mediaindonesia.com/news/read/58308/survei-csistingkat-korupsi-di-indonesia-meningkat/2016-07-26, di akses pada hari Senin 24 April 2017, jam $14: 00 \mathrm{Wib}$

Ekawaty Rante Liling, Firmanto Adi Nurcahyo, Karin Lucia Tanojo, Hubungan Antara Kecerdasan Spritual dengan Prokrastinasi Pada Mahasiswa Tingkat Akhir, Jurnal Humanitas Vol, X No. 2 Tahun 2013.

Gantina Komalasari, Eka Wahyu dan Karsih, Teori dan Praktek Konseling, Jakarta : PT Indeks, 2011.

Gerald Corey, Teori dan Praktek Konseling \& Psikoterapi, Bandung: PT Refika Aditama, 2010.

M. Nurul Irfan, Korupsi Dalam Hukum Pidana Islam, Jakarta: Amzah, 2014.

Ramdani, Pengembangan Konsep Spritual Dalam Pelaksanaan Layanan Konseling, Jurnal Kopasta, Vol 3 No 2 Tahun 2016.

Zainal Abidin, A Gimmy Prathama Siswadi, 2015, Psikologi Korupsi, Bandung: PT Remaja Rosdakarya. 